\title{
Anioł Doūhird, Philosopher of Vilna
}

\author{
BY
}

\section{R. J. PATRY-TAMUŠANSKI}

One of the most representative philosophers of the early 19th century in Byelorussia, Lithuania and Poland was Anioł Doūhird, who was born on the 11th of December 1776 in Jurkoūščyna in the Mścisłau district of the province of Mahilou to the family of the nobleman Andrej Doūhird (Dowgird).

His primary education Doūhird first received from his father. Afterwards he was sent in 1786 to the Jesuit schools in Mścisłaū and Mahilou, where the boy showed marked abilities in his various studies. Later Doūhird studied in Dubrovno in the school of the Piarist Fathers. His subjects included rhetoric, physics, history, Latin, French and logic.

Here Dounhird became acquainted with the works of the modern philosophers as well as those of Antiquity.

In the year 1791 he entered the Congregation of Piarists in Dubrovno in the province of Minsk and in due course was ordained priest. From 1793 to $1807^{2}$ he taught mathematics, physics and elocution in the schools of his Congregation, which were said to be of a very high standard. ${ }^{3}$

Two years later in 1809 Anioł Doūhird was called to the theological seminary of the University of Vilna, where he was to fulfil the office of chaplain. ${ }^{4}$

He remained at the university until its closure in 1832. Doūhird lectured in philosophy for two periods of his life. The first was from the beginning of the academic year 1818 until 1823, and the second from the spring of 1824 until his death in 1835. After the University of Vilna was closed, Dounhird lectured in the Theological Seminary as Professor of Philosophy.

In his approach to philosophy Doūhird was primarily a psychologist, as we shall see later. Apparently Doūhird did not make much

1. E. K. Doroševič, Anioł Dovgird - myslitel' epochi Prosveščenija Minsk, 1967, pp. $20 \mathrm{ff}$.

2. H. Struve, Wyklad systematyczny logiki, Warszawa, 1870, p. 209.

3. J. Łukaszewicz, Historya szkót $w$ Koronie $i$ W. K. Litewskim, IV, Poznań, 1851, p. 197.

4. M. Straszewski, Dzieje filozoficznej myśli w okresie porozbiorowym Kraków, 1912, pp. 385-86. 
of an impression as a professor of philosophy. The historian of philosophy, M. Straszewski, taking note of various memoirs of Doūhird's students, tells us that Doūhird was nervous, kept only to the written notes and text before him, and still became frequently confused, forgetting what he wanted to say. He was often unable to control his students. Lectures were held irregularly so they were consequently poorly attended. ${ }^{5}$

None the less H. Struve in his Historyja logiki considers Doūhird's works as occupying an important and interesting place in the history of logic in Poland. ${ }^{6}$ However bad his lectures, his various works are written in a good philosophical style, though at times they tend to be lengthy.

From 1833 till his death on 26th April 1835 Doūhird was one of the Canons of Vilna Cathedral. ${ }^{7}$ He died at the age of 59.

Having given brief biographical information about our philosopher, we shall now turn to his works.

As with most philosophers the works of A. Doūhird, though not all were published, are the fruits of an industrious scholarly life.

The first work of Dounhird's to be published was a critical review of the book $O$ jilozojii by Felix Jaroński. This review appeared in the Dziennik Wileński in the year 1817. In these articles Dounhird reveals much of his original philosophical thought, ${ }^{8}$ and takes a decisive stand against that idealism which negates the objective character of the laws of science and philosophy.

Doūhird shows that the source and basis of Jaroński's philosophy is idealism, which is far from the true method developed in Logic.

The second work of our philosopher to appear in print developed from his course of lectures at the University of Vilna. This work bears the title $O$ logice, metafizyce $i$ filozofii moralniej and was published in Vilna in 1821. The book is in two parts, the first of which is a treatment of logic, which Doūhird never separated from psychology. The second part is a study of the development of metaphysics as a science up to the new doctrines of Wolff and the transcendental philosophy of Kant. This work is also of a critical character, for Doūhird strives to show the meagre value of some of these philosophies in the true progress of knowledge. ${ }^{10}$

Chronologically the dissertation Doūhird wrote for his doctoral degree followed in 1826: Dissertatio inauguralis theologico-dogmatica de miraculis. This work remained unpublished.

Two years later, in 1828, the first part of his Wykład przyrodzonych myślenia prawidet, czyli logika teoretyczna $i$ praktyczna, was published in Połack. Two further parts of this work remain in manuscript only.

5. Ibid., p. 386 .

6. Struve, Historya logiki jako teoryi poznania, Warszawa, 1911, p. 238.

" , Wykład, p. 208.

7. Struve, Historya logiki, p. 245.

8. Iz istorii ftlosofskoj $i$ obščestvenno-političeskoj mysli Belorussii, Minsk, 1962, p. 401.

9. S. Kaczmarek, Anioł Dowgird, filozof nieznany, Warszawa, 1965, pp. 62-70.

10. Ibid., pp. 70-1. 
In the introduction ${ }^{11}$ to part one, Doūhird calls this extensive work the fruit of twenty years' meditation and it is indeed of monumental importance for its author - i.e. his life's work. Struve ${ }^{12}$ considers it a pity that only the first part was published, although it appears that it had been approved for printing in its entirety. ${ }^{13}$ In both his works, Struve critically analyses and evaluates Doūhird's book.

The third important published source for the thought of Aniot Doūhird was published posthumously in 1839 under the title Rzeczywistość poznań ludzkich in the Vilna journal of studies Wizeruriki $i$ roztrzasania naukowe, Poczet nowy, drugi, V, pp. 5-81. This was considered by Straszewski ${ }^{14}$ to be the most important as it forms a synthesis of Doūhird's philosophy.

Unfortunately the other works of Doūhird remain in manuscript. They are:

1. The second and third parts of the above mentioned Wykład przyrodzonych myślenia prawidet,

2. A history of Philosophy,

3. Research on the Philosophy of Kant,

4. Moral Philosophy,

5. Remarks on psychology,

6. Remarks on the souls of animals,

7. Philosophical notes,

8. Rudimenta logicae,

9. Natural Theology,

and other works of a theological nature, or dealing with the spiritual life, such as sermons, retreat conferences, etc.

Of late, interest in this little-known Byelorussian philosopher has revived and we find two excellent studies of his works by the Polish scholar S. Kaczmarek and his Byelorussian counterpart E. K. Doroševič. ${ }^{16}$

These two books handle some of the ideas contained in the unpublished manuscripts otherwise unfortunately not easily accessible to the student. At present there are no writings about Doūhird in any western European language.

Although most of the works of Anioł Dounhird were written either in Polish or in Latin, this has little bearing on the fact that he was a Byelorussian. Scholars have always tried to use as a vehicle of communication that language most widely used in the academic milieu in which they find themselves. Thus many of the works of Leibniz are in French. Doūhird, a nineteenth century philosopher in Vilna, used Polish.

Progressing now to a brief exposition of the philosophical ideas of Douhird we may well note that at the end of the 18th and beginning of the 19th centuries the ideas of the Enlightenment were being

11. A. Dowgird, Wykład przyrodzonych myślenia prawidel czyli Logika teoretyczna i praktyczna, Połock, 1828, p. XLI.

12. Struve, Wyklad, p. 203.

13. Kaczmarek, op. cit., p. 72.

14. Straszewski, op. cit., p. 387.

15. Kaczmarek, op. cit., p. 79.

16. See above, notes 1 and 9. 
propagated in Byelorussia. In lecture halls and in libraries works of French thinkers of the 18th century began to appear, and along side of works of Staszic, Piramovič, the Sniadiecki brothers, those of Voltaire, Rousseau, Buffon, and others were found.

The social and economic structure of Byelorussia was then conducive to the spread of the ideas of the Enlightenment. ${ }^{17}$

In addition to the above-mentioned philosophers, the thoughts of the philosopher of Konigsberg, Immanuel Kant were still making their impact felt in Byelorussia, Lithuania, and Poland ${ }^{18}$ in the first half of the nineteenth century.

A. Doūhird was also interested in the empiricist philosophers Locke, Berkeley and Hume, and was particularly familiar with the works of Kant and his transcendental philosophy. Doūhird belongs to those thinkers who were greatly influenced by the ideas of this philosopher. This influence can be seen in his theory of knowledge and in his moral philosophy, although we cannot consider him completely dependent on Kant. Indeed in many points he takes a different stand from Kant, and is independent of his transcendental idealism.

There would seem to be three main sources from which the thoughts of Doūhird flow, namely - Kantian criticism, the psychological school, and Catholic Christianity. ${ }^{19}$

As a point of departure Doūhird uses Kant. 'Orderly logic must fundamentally explain the boundaries described by the reasoning power of man, differentiate false from true evidence, opinion from certainty, as well as elucidate the various degrees and kinds of probability'. $^{20}$

Kant questioned the possibility of knowing an object in itself and in what way being can be. This he considered the first and primary problem of philosophy. With Kant Doūhird further differentiates two principles of knowledge - the first is given us by our mind itself; the second is obtained from external objects. The first source of knowledge, however, Doūhird does not call a priori but natural, and here we can already notice a divergence from the thought of Kant. Dounhird prefers to use psychology to differentiate the natural ideas from those acquired from outside, and considers logic as true and useful only when it serves not only the form but also the matter of thought - in other words, formal truth must not contradict material reality. ${ }^{21}$

Thus Doūhird is convinced that our senses really perceive an object - a material being outside of us, and what we first comprehend are its qualities. ${ }^{22}$ His theory of knowledge (note that this is psychology rather than formal logic) concludes that the objects must in some way touch the senses.

17. Iz istorii filosofskoj ...., p. 398.

18. Kaczmarek, op. cit, pp. $11 \mathrm{ff}$.

19. Straszewski, op. cit., p. 388.

20. Dowgird, op. cit., p. IV.

21. Ibid., p. XV.

22. Ibid., p. 33. 
Doūhird explains: 'It is nature itself that gives man knowledge of why sensations acting in him tell him to judge their causes as having existence outside of his being. Therefore we admit that the intellect in the case of a false judgement makes an error, which the very nature of our mind tells us. But in itself such a confirmation (i.e. on the part of the mind $-R$. P.-T.) would be contradictory. Thus the truth is that which is in accordance with the natural rules of thought and error is what is aberrant from this. If someone thinks correctly we say that his thought was natural, but if someone makes a false conclusion we are accustomed to say that such a conclusion is unnatural. It is evident, then, that truth and nature play an equal part in the expression of thought'. ${ }^{23}$

As in Kant, a difficulty arises here. Certain knowledge is not outside in the world but seems to be in the mind. Dounhird recognises even the substance and accidents of sense perception as elements in knowing an object, whereas Kant regarded the form of perception as an a priori function of the object, the elements of sense perception originating in it from experience. ${ }^{2}$

However from all this one must not consider Doūhird as an idealist or sceptic in the style of Berkeley or Hume. Dounhird recognises the role of sense knowledge in intellection and considers intellectual knowledge to be more perfect in proportion to the perfection of the information received from the senses.

Doūhird considers the elements of our senses in accord with empiricist philosophy as something subjective. Time and space he recognises as having existence independent of our minds.

The soul, time and space, causality are, according to Doūhird, 'previous ideas' ('wyobrażenia przedniejsze') to which existence belongs without reference to anything else.

But we cannot know reality directly in itself, neither does our philosopher consider this deeper knowledge necessary for us. ${ }^{25}$

In briefly considering Doūhird's thoughts on metaphysics one can see the critical approach, if in a somewhat altered form. He considers methaphysics as the 'science progressing from objects of sense knowledge to the exposition of such things which only the mind can grasp'. ${ }^{26}$

Furthermore Doūhird treats logic as a part of psychology, and psychology in many ways as pertaining to metaphysics. Thus he would consider metaphysics as having two parts - psychology including logic, and natural theology.

Concerning the existence of God Doūhird proposes four 'proofs':

1. The necessity of accepting a first cause.

2. 'Correctness' ('Prawidłowość') revealing itself in our reason, but but not dependent on the mind itself.

3. The order and dependence in the universe.

4. Moral law and the voice of conscience. ${ }^{27}$

23. Ibid., p. 54.

24. Ibid., p. 118.

25. Straszewski, op. cit., pp. 390-1.

26. Dowgird, O logice, metafizyce $i$ filozofii moraine], Wilno, 1821, p 260

27. Ibid., p. 253. 
Of these proofs only the second would seem to be tied in with the critical approach and reflects transcendentalism. The fourth shows a return to Kant and his categorical order. Kaczmarek considers that the metaphysical thoughts of Doūhird represent rather a return to the thoughts of Thomas Aquinas. ${ }^{28}$

The prime difference between Kant and the philosopher of Vilna in their ethics and philosophy of religion is that Kant suggests the idea of a Divinity from the point of the critical order, but for Dounhird the order takes its origin from a Supreme Being. Doūhird's ethics are a combination of Christian moral teachings and those of Kant. ${ }^{29}$

Anioł Doūhird approached philosophy primarily from a psychological view point. He was no doubt acquainted with the psychologists of the Age of Enlightenment. But from some of the theories advanced in unpublished manuscripts studied by Doroševič, we may deduce that Doūhird had an insight into theories which were to appear only much later.

For example, original ideas are contained in the manuscript Krótkie uwagi nad dusza zwierzat. Our philosopher believed that higher animals possess many characteristics of rational activities such as analysis, synthesis, memory. But they are unable to exercise abstraction and cannot pass the information gathered on to subsequent generations. A conclusion reached by animal psychology today! ${ }^{30}$

It would be beyond the scope of this general introduction to Doūhird's philosophical thought to deal in detail with all the interesting facets of this man's ideas. In some fields he showed great originality of thought, in others he merely repeated the ideas of Kant and of scholastic philosophy.

One apparent weakness is Doūhird's confusion of logic with psychology. For him logic is nothing other than a part of psychology, albeit the greatest and most important. Often this causes a lack of exactness and destroys the clearness of communicating his thought to the reader. None the less, the philosophical thought of Anioł Doūhird deserves further research and deeper study.

28. Kaczmarek, op. cit., p. 232.

29. Ibid., pp. $230 \mathrm{ff}$.

30. Doroševič, op. cit, pp. $194 \mathrm{ff}$. 